\title{
Socio-Economic Analysis and Land Suitability Mapping in the Development of Medicinal Plants (Biopharmaca) During COVID-19 Situation in Tinombo District, Parigi Moutong Regency, Indonesia
}

Ramlan

Faculty of Agriculture, Tadulako University, Palu 94118, Indonesia

Corresponding Author Email: ramlan.untad.palu@gmail.com

https://doi.org/10.18280/ijsdp.160515

Received: 12 February 2021

Accepted: 1 September 2021

\section{Keywords:}

medicinal plants (biopharmaca), socioeconomic, land suitability

\begin{abstract}
The research objectives were to analyze the socio-economic conditions of farmers while identifying the suitability level of the land and develop a mapping of high potential for medicinal plants (biopharmaca). The method used was purposive sampling carried out by conducting direct surveys, followed by sampling the soil at the research sites, and analyzing the socio-economic level of farmers in Tinombo District. The maps of slope class, soil, and land use were overlaid by using the ArcGIS 10.0 application. The observation revealed that in general, the socio-economic value of the farming community on the cultivation of medicinal plants was quite good. Farmers put a high level of interest, cultivation techniques, and land suitability, with an average of 2.22, 2.72, and 2.1, respectively. However, the level of knowledge on seedling and marketing parameters found low, with an average of 1.5 and 1.0, respectively. The analysis of soil samples seemed to determine the land suitability. The $\mathrm{pH}$ parameter $\mathrm{H}_{2} \mathrm{O}$ has a value ranging from 5.81 to 7.09 , C-organic was $1.14-6.37 \%$, total Nvalue was 0.28 to $0.49 \%$, P-availability was $3.29-130.55 \mathrm{ppm}$, and cation exchange capacity was $0.08-1.46 \mathrm{cmol}+/ \mathrm{kg}$. In the parameters of the exchangeable bases of the land, including $\mathrm{K}$ about $0.07-1.46 \mathrm{cmol}+/ \mathrm{kg}$, Ca about $0.13-8.88 \mathrm{cmol}+/ \mathrm{kg}, \mathrm{Mg}$ about $0.18-8.66 \mathrm{cmol}+/$ $\mathrm{kg}$, and $\mathrm{Na}$ about $0.10-0.18 \mathrm{cmol}+/ \mathrm{kg}$. Then, the soil base saturation parameter valued of $1.34-56.63 \%$. The characteristics of the cultivated land for medicinal plants, both chemical and physical, have been identified in order to create agricultural land with suitable characteristics of the cultivated plants.
\end{abstract}

\section{INTRODUCTION}

Currently the corona virus pandemic or COVID-19 is something that is most feared in the world. The very rapid spread of the COVID-19 pandemic outbreak not only has a wide impact on the world of health, but other sectors have also been affected by the virus. This condition has suppressed global economic growth and has resulted in wider social and economic impacts, including in the food and agriculture sectors. The agricultural sector is actually a safeguard against this outbreak, food is a priority need that must be met for all people so that agricultural production activities during the COVID-19 virus pandemic must continue [1]. The existence of this epidemic is actually a challenge for the agricultural sector because people desperately need adequate and healthy food [2].

One type of plant that can be developed in this situation is a biopharmaceutical plant. The production of this medicinal plant which can be used to overcome COVID-19 [3]. Medicinal plants (biopharmaca) are one of the non-timber forest products provided by nature, but these medicinal plants are often ignored because it is considered low economic value since awareness of the efficacy toward these medicinal plants shrubs look still low [4]. Biopharmaca plants are plants that are included in the horticulture sub-sector. Biopharmaca plants are plants that are useful for medicine, cosmetics and health which are consumed or used from plant parts such as leaves, stems, fruit, tubers (rhizomes) or roots [5]. Some medicinal plants also have an export economic value such as Morinda citrifolia, Andrographis paniculata, Phaleria macrocarpa, Zingiber officinale, and Curcuma longa Linn. syn. Curcuma domestica Val. [6]. Medicinal plants closely related to community life, both as a source of livelihood and income for farmers around the forest as well as a promising opportunity for many farming options ranging from pre to post cultivation [7].

Antioxidants in ginger function as free radical scavengers that can cause damage to body cells, The content of Gingerol in ginger functions to increase immunity while Oleoresin and Flavonoids as anti-inflammatory and essential oils as antimicrobial substances [8]. Galangal when it is processed into a drink can increase endurance, prevent and eliminate angina which is caused by chemical ingredients such as saponins, flavonoids, and polyphenols [9].

Parigi Moutong Regency is one of the producing areas for biopharmaceutical plants in Central Sulawesi with a variety of rhizome plants. The harvested area for biopharmaca in Parigi Moutong Regency has increased; in 2018 the harvest area was 9.21 $\mathrm{Ha}$ and increased to $11.43 \mathrm{Ha}$ in 2019 consisting of Ginger (3.83 Ha), Galangal (2.60 Ha), Aromatic ginger (1.13 $\mathrm{Ha}$ ), and Turmeric (3.86 Ha) [10]. Central Sulawesi released the poor population Parigi Moutong Regency is in the third 
rank of poor areas out of 13 districts/cities in Central Sulawesi Province [11]. The development of the agricultural sector is very important because considering the number of people working in agriculture is still very large [12]. Parigi Moutong Regency which has the potential to develop the agricultural sector to improve the community's economy, especially in the Medicinal Plants (Biopharmaca) sector.

Land evaluation is essentially the process of land potential estimation for various uses by comparing the requirements needed for a land-use with the natural resources exist on the land [13]. Land evaluation is part of the land-use planning process. The point of land evaluation is to compare the requirements demanded by the type of land use applied, with the properties or land quality held. In this way, the land potential or suitability class for the land use type will be identified [14].

Medicinal plants, in particular rhizome types, are known as one of the biopharmaceutical commodities in Central Sulawesi. In order to increase yield and production, it is suggested to improve the parameters affect the cultivation of these biopharmaceutical plants. Tinombo District is one of the highest producing areas of Medicinal Plants (Biopharmaca) in Central Sulawesi, this great potential must be maintained and developed especially in the aspect of agricultural land so that the production of Medicinal Plants (Biopharmaca) can continue and increase in order to meet the needs of Medicinal Plants (Biopharmaca) during the time of the covid-19 pandemic.

This study conducted the identification of the socioeconomic conditions of the farmers, evaluation of the chemical characteristics of the soil, and mapping the land of medicinal plants cultivation.

\section{METHOD}

The method used was purposive sampling implemented by direct survey in Tinombo District, Parigi Moutong Regency and continued with soil sampling as material for analysis in the Laboratory.

The stages of collecting research data, i.e.:

1. Collecting data of Medicinal Plant (Biopharmaca) Farmers in Parigi Mautong Regency. Medicinal Plants (Biopharmaca) data collection was carried out using primer data from farmer and secondary data sourced from the Central Statistics Agency in Parigi Moutong Regency, namely land area and annual production level.

2. Preparing slope maps, soil type maps, and land use maps as big maps. The activities carried out at this stage are: 1) determining the research area with a map of administrative boundaries, 2) preparing a land use type map, a soil type map and a slope map as a base map, 3) making a map of land units by overlaying. the maps mentioned above and at the same time determining the sampling point at the research location, 4) work preparation, field observations and observations and 5) preparing equipment that will be used for field activities.

3. Preparing land observation map units using ESRI Arc GIS software and planning data for the location of sampling points at the research sites.

4. Procurement of rainfall and temperature data from the Meteorology, Climatology and Geography (BMKG) stations in the last ten years, namely from 2009-2019
5. Distribution of Agricultural Socio-Economic Questionnaires.

\section{Data processing and mapping}

The results of the soil analysis in the Laboratory were processed and interpreted. The classification of land suitability classes for each SST referred to the Land Suitability Criteria Table sourced from the Soil Research Institute. Physical and chemical properties of the soil in each site were tested against the S1 criteria; if the land has met the criteria, it will be categorized as S1 class. However, if it does not meet the criteria, then it needs further analysis with the criteria for the S2 class. After interpreting the data and grouping the land suitability, the actual and potential land suitability map may be created.

\section{RESULTS \& DISCUSSION}

\subsection{Socio-economic analysis of farmers}

The survey on the socio-economic level of farmers on medicinal plant cultivation in this study involved 50 respondents. The assessment was carried out on five parameters, namely interest, knowledge level on cultivation technique, land suitability level, seeds, and marketing of rhizome type medicinal plant. The results of the socioeconomic measurement level of farmers related to the cultivation of biopharmaceutical plants were displayed in Figure 1.

Figure 1 shows that mostly the socio-economic value of the farming community on the cultivation of medicinal plants was quite good. Communities had high levels of interest, also knowledge of cultivation techniques, and land suitability, with an average of 2.22, 2.72, and 2.1, respectively. However, the knowledge of seedling and marketing parameters tended to low, with an average of 1.5 and 1.0, respectively.

Various problems for biopharmaca cultivation that were found were the cultivation method had not fully referred to the Standard Operating Procedure (SOP), the seeds / seeds used were not superior seeds / seeds resulting in low production, fluctuating prices, limited business capital, no market guarantee, and limited access market information.

The development of medicinal plant farming is constrained by the seed factor. Other studies have shown that the problem faced by farmers is the lack of information on the use of quality seeds and limited research on seedlings, so that many farmers still use seeds that are not of guaranteed quality [15]. As a result, productivity and product quality are still low.

The propagation of medicinal plants can be done in various ways, namely:

1) Using true seeds such as KB (Solanum khasianum), sambiloto (Andrographis paniculata), purwoceng (Pimpinella pruatjan), crown of god (Phaleria macrocarpa), basil (Occimum sp.), saga (Abrus precatorius), secang (Caesalpinia sappans), and noni (Morinda nitrifolia),

2) Using rhizomes such as ginger (Zingiber officinale), turmeric (Curcuma domestica), kencur (Kampheria galanga), temu lawak (Curcuma zanthoriza), and temu white (Curcuma zeodaria),

3) Using cuttings such as betel (Piper betle), katuk (Sauropus androgynus) and Javanese chili (Piper cubeba), 
and,

4) Using tillers and stolons such as citronella (Andropogon nardus) and gotu kola (Centella asiatica)) [15].

The marketing strategy is still conventional, which depends on village collector traders whose marketing chain is long so that the margins of business results are relatively low because the prices given by village collectors are not in accordance with market prices. Increasing farmers' income can be done through product handling and packaging of medicinal plant products. Handling of agricultural products and packaging is carried out to increase the added value of agricultural products and the selling price. Value-added processing and direct marketing are commonly recommended strategies for increasing income and improving the economic viability of small farms [16].

In addition, the absence of an integrated marketing model for biopharmaca crops and the capacity of farmers and their institutions is still very limited. Therefore, increasing the capacity of human resources and institutional capacity for agricultural development and marketing of biopharmaceutical commodities in Tinombo District, Parigi Moutong Regency, needs to carry out various training and mentoring activities.

The trainings that need to be carried out are (a) training and guidance on GAP for biopharmaca cultivation, equipped with making demonstration plots, (b) training and guidance on the processing of rhizomes into simplicia with GMP, (c) production management training, and (d) entrepreneurship training and marketing management for farmers and intermediate traders [17].

\subsection{Land suitability evaluation}

Determination of the land suitability for biopharmaca cultivation was carried out through the evaluation of soil samples. The parameters used include $\mathrm{pH} \mathrm{H}_{2} \mathrm{O}$, C-organic, $\mathrm{N}$ Total, P-availability, Cation Exchange Capacity (CEC), exchangeable bases (K, $\mathrm{Ca}, \mathrm{Mg}$, and $\mathrm{Na}$ ), and Base Saturation (KB).

The $\mathrm{pH}$ parameter $\mathrm{H}_{2} \mathrm{O}$ valued ranging from 5.81 to 7.09 , the C-organic value ranged $1.14-6.37 \%$, the total $\mathrm{N}$-value ranged $0.28-0.49 \%$, the $\mathrm{P}$ - availability ranged $3.29-130.55$ ppm, and the cation exchange capacity was $0.08-1.46$ $\mathrm{cmol}+\mathrm{kg}$. In the parameters of the exchangeable bases on the soil, including $\mathrm{K}$ valued $0.07-1.46 \mathrm{cmol}+/ \mathrm{kg}$, Ca was 0.13 $8.88 \mathrm{cmol}+/ \mathrm{kg}, \mathrm{Mg}$ was $0.18-8.66 \mathrm{cmol}+/ \mathrm{kg}$, and $\mathrm{Na}$ was $0.10-0.18 \mathrm{cmol}+/ \mathrm{kg}$. Then, the soil base saturation parameter had a value of $1.34-56.63 \%$ (Table 1 ).

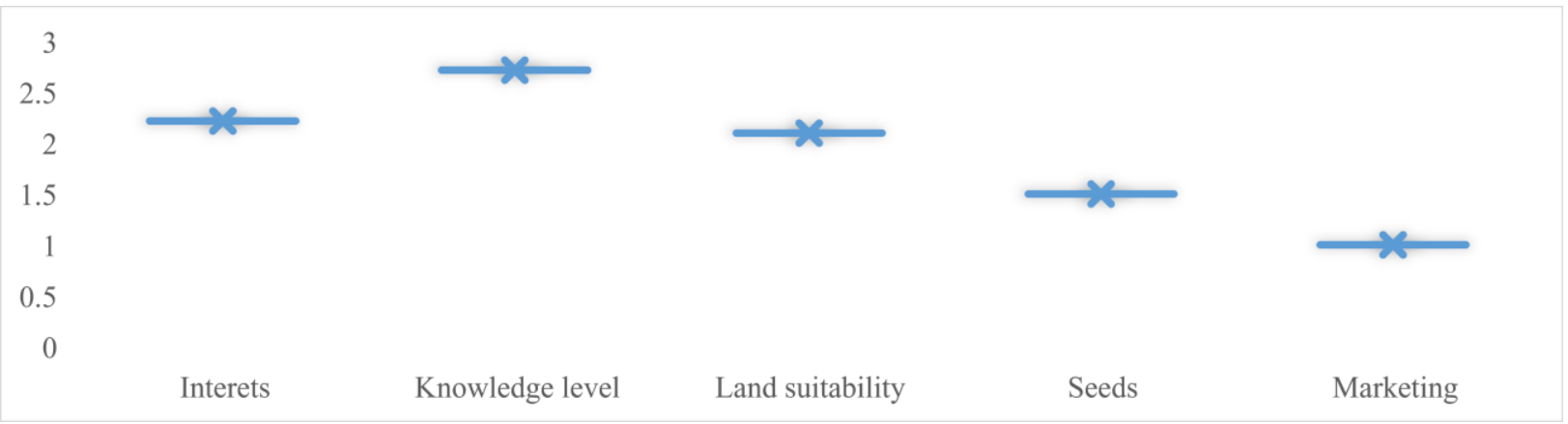

Figure 1. Graph of the level of interest and knowledge of the community towards medicinal plant cultivation

Table 1. Result of land suitability analysis

\begin{tabular}{|c|c|c|c|c|c|c|c|c|c|c|}
\hline \multirow{2}{*}{ Sample } & \multirow{2}{*}{$\begin{array}{c}\mathbf{p H} \\
\mathbf{H}_{2} \mathbf{O} \\
{[18]}\end{array}$} & \multirow{2}{*}{$\begin{array}{c}\text { C-Organic } \\
(\%)[19]\end{array}$} & \multirow{2}{*}{$\begin{array}{c}\text { N-Total } \\
(\%)\end{array}$} & \multirow{2}{*}{$\begin{array}{c}\text { P-availability } \\
\text { (ppm) }\end{array}$} & \multirow{2}{*}{$\begin{array}{c}\text { CEC } \\
(\mathbf{c m o l + / k g}) \\
{[20]}\end{array}$} & \multicolumn{4}{|c|}{ Exchangeable Bases (cmol+/kg) [21] } & \multirow{2}{*}{$\begin{array}{c}\text { Base } \\
\text { Saturation } \\
(\%)[22]\end{array}$} \\
\hline & & & & & & $\mathbf{K}$ & $\mathbf{C a}$ & Mg & $\mathbf{N a}$ & \\
\hline 1 & $\begin{array}{l}6.55 \\
\text { (A) }\end{array}$ & $1.14(\mathrm{~L})$ & $0.49(\mathrm{M})$ & 3.29 (VL) & $7.08(\mathrm{VL})$ & $0.41(\mathrm{M})$ & $\begin{array}{l}1.79 \\
(\mathrm{VL})\end{array}$ & $\begin{array}{l}0.83 \\
(\mathrm{~L})\end{array}$ & $\begin{array}{c}0.10 \\
(\mathrm{~L})\end{array}$ & $44.22(\mathrm{M})$ \\
\hline 2 & $\begin{array}{l}6.49 \\
\text { (A) }\end{array}$ & $2.30(\mathrm{M})$ & $0.22(\mathrm{M})$ & $3.65(\mathrm{VL})$ & $13.67(\mathrm{~L})$ & $1.46(\mathrm{VH})$ & $\begin{array}{l}3.65 \\
(\mathrm{~L})\end{array}$ & $\begin{array}{l}2.49 \\
(\mathrm{H})\end{array}$ & $\begin{array}{c}0.14 \\
(\mathrm{~L})\end{array}$ & $56.63(\mathrm{H})$ \\
\hline 3 & $\begin{array}{l}6.39 \\
(\mathrm{~A})\end{array}$ & $3.54(\mathrm{H})$ & $0.33(\mathrm{M})$ & $64.97(\mathrm{VH})$ & $20.70(\mathrm{M})$ & $0.13(\mathrm{~L})$ & $\begin{array}{l}1.97 \\
(\mathrm{VL})\end{array}$ & $\begin{array}{l}2.27 \\
(\mathrm{H})\end{array}$ & $\begin{array}{c}0.11 \\
(\mathrm{~L})\end{array}$ & $21.64(\mathrm{~L})$ \\
\hline 4 & $\begin{array}{l}6.21 \\
(\mathrm{~A})\end{array}$ & $3.72(\mathrm{H})$ & $0.33(\mathrm{M})$ & $69.44(\mathrm{VH})$ & $19.87(\mathrm{M})$ & $0.13(\mathrm{~L})$ & $\begin{array}{l}8.88 \\
(\mathrm{M})\end{array}$ & $\begin{array}{l}0.58 \\
(\mathrm{~L})\end{array}$ & $\begin{array}{c}0.10 \\
(\mathrm{~L})\end{array}$ & $48.75(\mathrm{M})$ \\
\hline 5 & $\begin{array}{l}6.06 \\
\text { (A) }\end{array}$ & $2.42(\mathrm{M})$ & $0.28(\mathrm{~L})$ & $3.86(\mathrm{VL})$ & $17.52(\mathrm{M})$ & $0.14(\mathrm{~L})$ & $5.2(\mathrm{~L})$ & $\begin{array}{l}0.29 \\
\text { (L) }\end{array}$ & $\begin{array}{c}0.12 \\
(\mathrm{~L})\end{array}$ & $32.82(\mathrm{~L})$ \\
\hline 6 & $\begin{array}{l}5.81 \\
(\mathrm{~A})\end{array}$ & $6.37(\mathrm{VH})$ & $0.49(\mathrm{M})$ & $130.55(\mathrm{VH})$ & $66.15(\mathrm{VH})$ & $0.19(\mathrm{~L})$ & $\begin{array}{l}5.62 \\
(\mathrm{~L})\end{array}$ & $\begin{array}{l}8.66 \\
(\mathrm{H})\end{array}$ & $\begin{array}{c}0.18 \\
(\mathrm{~L})\end{array}$ & $22.15(\mathrm{~L})$ \\
\hline 7 & $\begin{array}{l}6.66 \\
(\mathrm{~N})\end{array}$ & $3.95(\mathrm{H})$ & $0.29(\mathrm{M})$ & $99.50(\mathrm{VH})$ & $13.72(\mathrm{~L})$ & $0.07(\mathrm{VL})$ & $\begin{array}{l}5.08 \\
(\mathrm{~L})\end{array}$ & $\begin{array}{c}0.81 \\
(\mathrm{~L})\end{array}$ & $\begin{array}{c}0.11 \\
(\mathrm{~L})\end{array}$ & $44.27(\mathrm{M})$ \\
\hline 8 & $\begin{array}{l}6.60 \\
(\mathrm{~N})\end{array}$ & $4.29(\mathrm{H})$ & $0.38(\mathrm{M})$ & $104.32(\mathrm{VH})$ & $22.88(\mathrm{M})$ & $0.09(\mathrm{VL})$ & $\begin{array}{l}4.99 \\
(\mathrm{~L})\end{array}$ & $\begin{array}{l}1.05 \\
(\mathrm{M})\end{array}$ & $\begin{array}{c}0.11 \\
(\mathrm{~L})\end{array}$ & $27.29(\mathrm{~L})$ \\
\hline 9 & $\begin{array}{l}6.06 \\
\text { (A) }\end{array}$ & $4.47(\mathrm{H})$ & $0.25(\mathrm{~L})$ & $162.77(\mathrm{VH})$ & $37.16(\mathrm{H})$ & $0.08(\mathrm{VL})$ & $\begin{array}{l}0.13 \\
(\mathrm{VL})\end{array}$ & $\begin{array}{l}0.18 \\
(\mathrm{VL})\end{array}$ & $\begin{array}{c}0.11 \\
(\mathrm{~L})\end{array}$ & $1.34(\mathrm{VL})$ \\
\hline 10 & $\begin{array}{l}7.09 \\
(\mathrm{~N})\end{array}$ & $5.52(\mathrm{VH})$ & $0.42(\mathrm{M})$ & $92.07(\mathrm{VH})$ & $23.97(\mathrm{M})$ & $0.09(\mathrm{VL})$ & $\begin{array}{l}8.41 \\
(\mathrm{M})\end{array}$ & $\begin{array}{l}2.18 \\
(\mathrm{H})\end{array}$ & $\begin{array}{c}0.11 \\
(\mathrm{~L})\end{array}$ & $44.99(\mathrm{M})$ \\
\hline
\end{tabular}

Note: $\mathrm{A}=\mathrm{Acid}, \mathrm{N}=$ neutral, $\mathrm{VL}=$ very low, $\mathrm{L}=$ low, $\mathrm{M}=$ medium, $\mathrm{H}=$ high, $\mathrm{VH}=$ very high 


\subsection{Map of potential land for medicinal plants cultivation}

Observation of rhizome biopharmaca cultivation land was carried out by mapping the soil types (Figure 2), land map units (Figure 3), slope classes (Figure 4), and land cover (Figure 5) in Tinombo District, Parigi Moutong Regency, Central Sulawesi. In Figure 2, it is revealed that based on the soil type map, Tinombo District was dominated by soil types of typic Eutrudepts, typic Dystrudepts, and typic Hapludults, respectively. In Figure 3, the mapping of Land Map Units was dominated by conservation areas, primary dryland forest, and secondary dryland forest, followed by fields of typic Hopludults $23-40 \%$ (hilly), areas of typic scrub and plantation areas of typic Hapludults of $25-40 \%$ (hilly), and plantation areas of Endo aquepts 1-3\% (slightly flat). Based on Figure 4, the regional slope class map was dominated by the mountainous slope (> 40\%), followed by hilly land (25-40\%), and small hilly (15-25\%). Through the land cover map, it was dominantly covered by conservation areas, primary dryland forest, and secondary dryland forest, followed by fields, shrubs, and plantations areas.

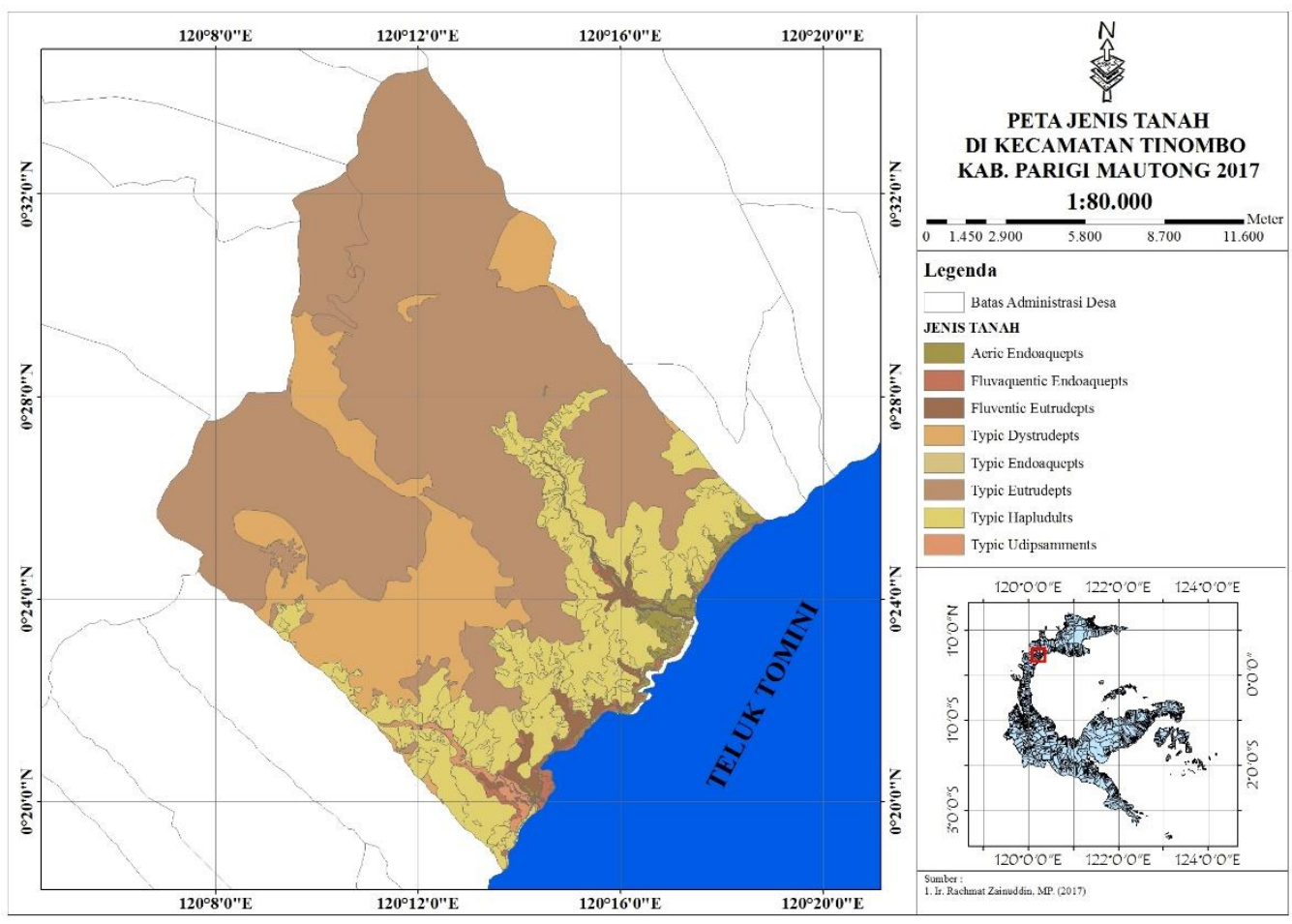

Figure 2. Map of soil types in Tinombo District

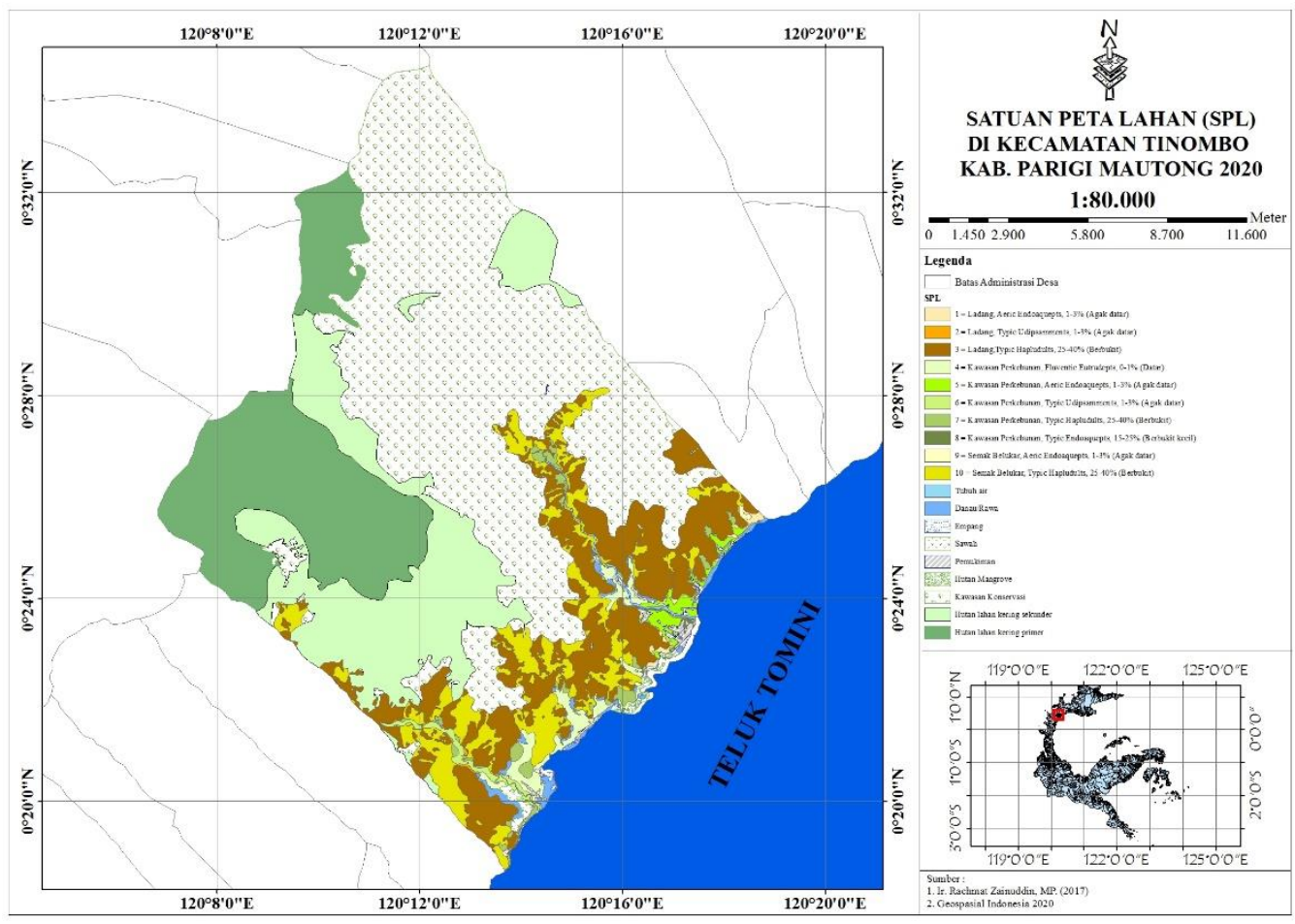

Figure 3. Map of land map unit in Tinombo District 


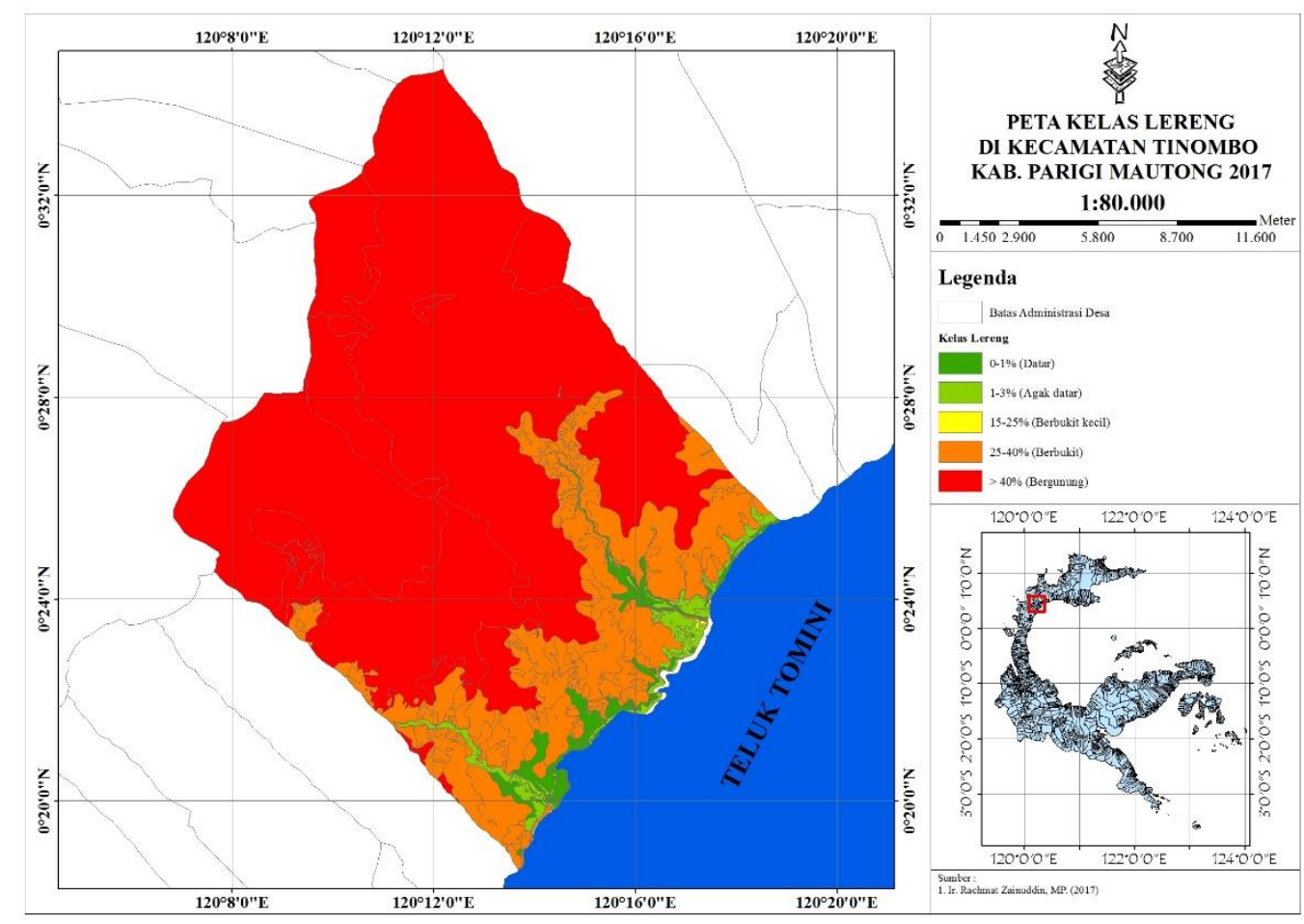

Figure 4. Map of slope class in Tinombo District

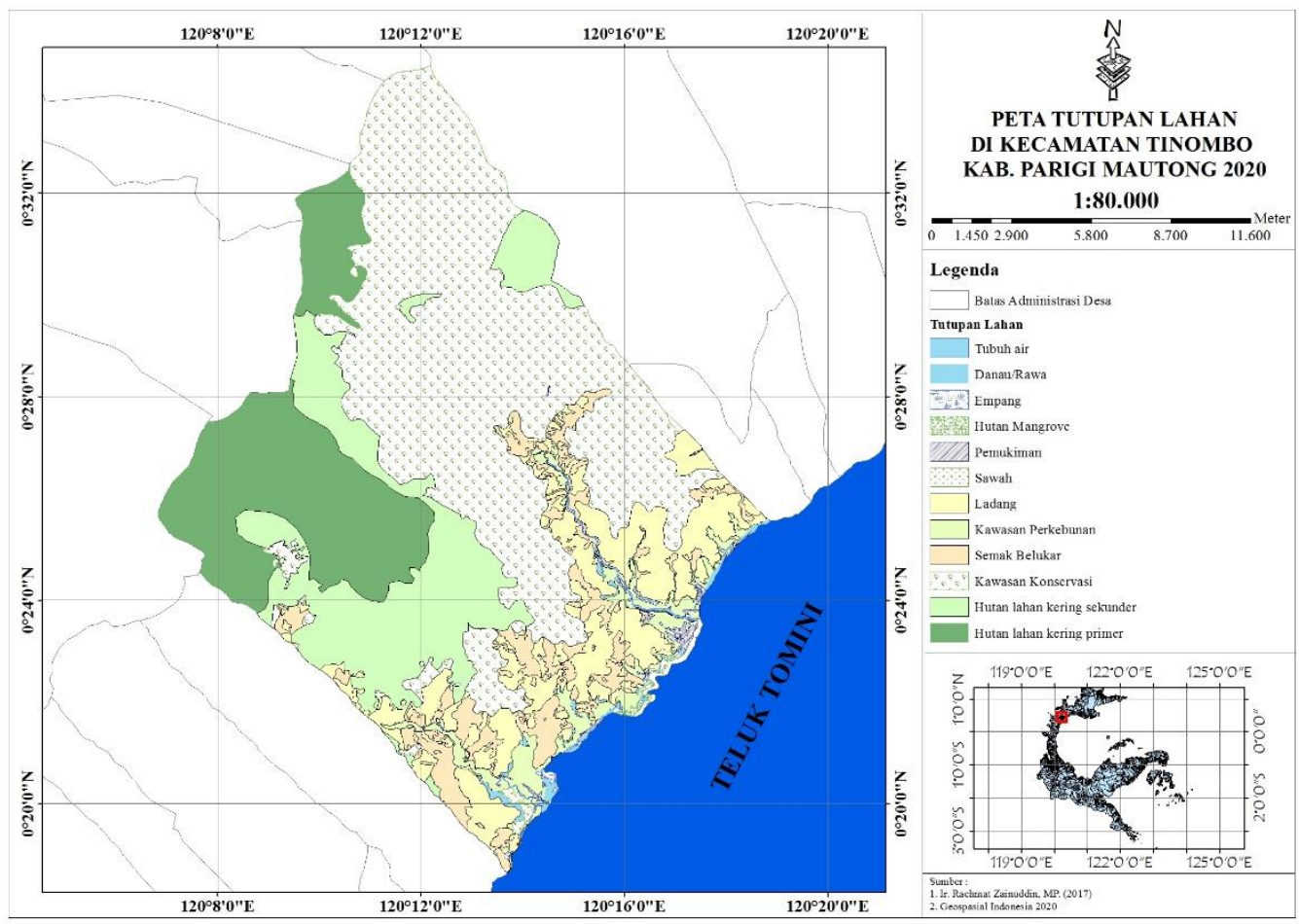

Figure 5. Map of land cover in Tinombo District

Medicinal plants are a plant type in which part of these plants may use as medicine, ingredients, or medicinal ingredients. Medicinal plants are all plant species known or believed to have medicinal properties [23]. The existence of medicinal plants in Indonesia is spread throughout Indonesia [24]. Ginger is a spice of commercial and medicinal importance [25]. Indonesia is rich in plant species with potential as medicinal properties, including rhizomes. The use of rhizomes, including turmeric, aromatic ginger, ginger, as medicine, has long been practised by the Indonesian people traditionally which are now starting to be developed on a manufacturing scale. The use of rhizomes both on a household scale and in factory production influenced the improvement in demand for raw materials, which in turn will affect the cultivation of this medicinal plant. Ginger can be used in the form of fresh paste, ginger tea, dried powder, preserved slices, cookies, candy, teas, tinctures, soda, jam, beer, capsule and syrup etc. [25].

The success of cultivation influenced by various interrelated factors, such as farmers' interests and knowledge, as well as the suitability of land, both chemically and physically [26-28]. The socio-cultural factors of farmers in the form of interest, 
knowledge of cultivation techniques, land suitability, seedlings, and marketing may influence the practice of cultivating medicinal plants. The higher a person's interest, the more his effort will be in practising it. A person's interest will determine the intrinsic motivation of an object, motivate discussion, receive information and find a way out for a problem which will then be realized in the form of activity [29]. The level of knowledge of cultivation techniques and suitability of agricultural land among farmers is also fundamental in influencing the success rate of farmers [30]. This ability supports the need for basic knowledge of agricultural practices. However, insufficient knowledge of marketing may become an obstacle to cultivation practices in the community [31]. Marketing as the final point of return on capital is vital for farmers, the better marketing knowledge, the better decision of the farmers will be according to their agricultural conditions.

In terms of natural resources, the land suitability, both physical and chemical, is critical to improving. In Ethiopia, degradation of land fertility due to steep slope classes is a severe problem for agricultural productivity even though almost all soil fertility parameters will still decline in the long term; thus the land quality management is needed [32]. Each plant species tends to have different land characteristics. Soil chemical characteristics may influence the growth of cultivated plants. Nutrients and chemicals contained in cultivation land affect the growth also nutritional and nonnutritional content of cultivated materials [33].

Soil suitable for ginger cultivation is soil that contains lots of organic matter, is fertile and loose [34]. The most suitable soil types are latosol red brown, andosol. The ideal $\mathrm{pH}$ for growing ginger plants is between 6.8-7.0 [35]. Tinombo District has high productivity of medicinal plant commodities due to intensive management of medicinal plants. Tinombo District gives a big contribution as a center of medicinal plant production in Central Sulawesi and such contribution is supported by potentials of lands used for development of medicinal plants. The application of organic cultivation system was found more beneficial and significantly improved morpho-physiological traits, growth parameters, biochemical constituents, yield and yield components [36].

The limitation of the research is that the area of land used is still limited and efforts have not been made to improve the quality of the soil that is used as medicinal plants. Therefore, the next research is an analysis of soil quality improvement so that it is known which soil improvement materials are good and appropriate in improving soil quality, especially the development of medicinal plants. Then conduct research on the implementation of medicinal plant agribusiness areas that can improve the economy of farmers.

\section{CONCLUSIONS}

In general, the socio-economic value of the farming community on medicinal plant cultivation categorized as quite good. The community has a high level of interest, also knowledge of cultivation techniques, and land suitability. However, the level of knowledge about seedling and marketing tends to low. The characteristics of the cultivated land for medicinal plants, both chemical and physical have been identified in order to create agricultural land that is suitable with the characteristics of the cultivated plants. The implications of the research results encourage the government together with farmers to make efforts to improve land quality in order to develop crop potential and have an impact on improving the farmers' socio-economy especially Medicinal Plant (Biopharmaca).

\section{ACKNOWLEDGEMENTS}

Thanks to the Rector of Tadulako University, Chairman of LPPM of Tadulako University, and the Dean of the Faculty of Agriculture, Tadulako University, who support the finance this research. This research received funding from Tadulako University.

\section{REFERENCES}

[1] FAO. (2020). FAO - news article: COVID-19 and Agroecology reading list. http://www.fao.org/agroecology/slideshow/newsarticle/en/c/1268856/, accessed on Feb. 4, 2021.

[2] Basit, A., Murdiana, N., Waryanto, B., Chaidirsyah, R.M., Hermanto, Yulianto. (2020). Dampak COVID-19 Terhadap Sektor Pertanian. Buletin Perencanaan Pembangunan Pertanian, 1(2): 1-75. http://perencanaan.setjen.pertanian.go.id/public/upload/f ile/20200415123744BULETIN-EDISI-KHUSUS.pdf.

[3] Benarba, B., Pandiella, A. (2020). Medicinal plants as sources of active molecules against COVID-19. Front Pharmacol, https://doi.org/10.3389/fphar.2020.01189

[4] Iqbal, M., Septina, A.D. (2018). Pemanfaatan hasil hutan bukan kayu oleh masyarakat lokal di kabupaten sanggau, kalimantan barat. Jurnal Penelitian Ekosistem Dipterokarpa, $\quad 4(1)$ : $19-34$ https://doi.org/10.20886/jped.2018.4.1.19-34

[5] United States Department of Agriculture. (2017). Medicinal Botany - Plant Parts Used. https://www.fs.fed.us/wildflowers/ethnobotany/medicin al/parts.shtml, accessed on Feb. 4, 2021.

[6] Siregar, R.S., Hadiguna, R.A., Kamil, I., Nazir, N., Nofialdi. (2020). Demand and supply analysis of traditional medicinal plants in sumatera utara. Jurnal Tumbuhan Obat Indonesia, 13(1): 50-59. https://doi.org/10.22435/jtoi.v13i1.2037

[7] Sitepu, Sutikno. (2001). Peranan Tanaman Obat dalam Pengembangan Hutan Tanaman (The Role of Medicinal Plants on Plant on Plantaion Forest Development). Buletin Kehutanan, 2(2): 14-18.

[8] Danwilai, K., Konmun, J., Sripanidkulchai, B., Subongkot S. (2017). Antioxidant activity of ginger extract as a daily supplement in cancer patients receiving adjuvant chemotherapy: A pilot study. Cancer Manag Res, 9: 11-18. https://doi.org/10.2147/CMAR.S124016

[9] Cheah, P.B., Gan, S.P. (2000). Antioxidative/Antimicrobial effects of galangal and alpha-tocopherol in minced beef. J Food Prot, 63(3): 404407. https://doi.org/10.4315/0362-028x-63.3.404

[10] Badan Pusat Statistik, Kabupaten Parigi Moutong Dalam Angka. Kabupaten Parigi Moutong: BPS Kabupaten Parigi Moutong, https://parigimoutongkab.bps.go.id/.

[11] BPS Sulawesi Tengah, Profil Kemiskinan di Sulawesi Tengah September 2020. Palu: Badan Pusat Statistik 
Provinsi Sulawesi Tengah, 2021. https://sulteng.bps.go.id/pressrelease/2021/02/15/946/pr ofil-kemiskinan-di-sulawesi-tengah-september2020.html.

[12] Nursyafa'ah, Abd. Rauf, R., Hadayani. (2018). Income and feasibility analysis of wetland rice farming in sienjo village Toribulu sub district of Parigi Moutong regency. e-J. $\quad$ Agrotekbis, 6(2): 232-238. http://jurnal.faperta.untad.ac.id/index.php/agrotekbis/art icle/view/353.

[13] Sitorus. (2004). Evaluasi Sumberdaya Lahan. Bandung: Penerbit Tarsito https://stela2010.files.wordpress.com/2010/05/sitorusbab-x.pdf.

[14] Hardjawigeno, S., Widiatmaka. (2007). Evaluasi Kesesuaian Lahan dan Perencanaan Tataguna Lahan. Yokyakarta: Gadja Mada University Press. https://ugmpress.ugm.ac.id/id/product/pertanian/evaluas i-kesesuaian-lahan-dan-perencanaan-tataguna-lahan.

[15] Hasanah, M., Rusmin, D. (2006). Teknologi Pengelolaan Benih Beberapa Tanaman Obat Di Indonesia. Jurnal Litbang Pertanian, 25(2): 68-73.

[16] Clark, S. (2020). Financial viability of an on-farm processing and retail enterprise: A case study of valueadded agriculture in rural Kentucky (USA). Sustainability, $12(2)$ : 708 . https://doi.org/10.3390/su12020708

[17] Sundawati, L., Purnaningsih, N., Purwakusumah, E.D. (2014). Pengembangan Model Kemitraan dan Pemasaran Terpadu Biofarmaka dalam Rangka Pemberdayaan Masyarakat Sekitar Hutan di Kabupaten Sukabumi, Provinsi Jawa Barat | Jurnal Ilmu Pertanian Indonesia. Jurnal Ilmu Pertanian Indonesia, 17(3): 153-158.

[18] Kalra, Y. (1995). Determination of $\mathrm{pH}$ of soils by different methods: Collaborative study. Journal of AOAC International, 78(2): 310-324. https://doi.org/10.1093/jaoac/78.2.310

[19] Huang, P.T., Patel, M., Santagata, M.C., Bobet, A. (2009). Classification of Organic Soils. US: School of Civil Engineering, Purdue University.

[20] Nursyamsi, D., dan Suprihati. (2005). Soil chemical and mineralogical characteristics and its relationship with the fertilizers requirement for rice (Oriza sativa), Maize (Zea mays) and Soybean (Glycine max). Bul. Agron, 33(3): 40-47.

https://media.neliti.com/media/publications/7983-none5861bd9a.pdf.

[21] Kurniawan, H.F., Marpaung, P., Jamilah. (2018). Lowland rice soil classification at village Sukorejo subdistrict Sei Balai, district of Batubara based on soil taxonomy 2014. Jurnal Online Agroekoteknologi, 6(2).

[22] Rofik, A., Sudarto, S., Djajadi, D. (2019). Analysis and evaluation soil chemical properties on tobacco land of Kemloko variety at the tobacco centre of temanggung regency, central java. JTSL, 6(2): 1427-1440. https://doi.org/10.21776/ub.jtsl.2019.006.2.23

[23] Ivanova, D., Gerova, D., Chervenkov, T., Yankova, T. (2005). Polyphenols and antioxidant capacity of Bulgarian medicinal plants. Journal of Ethnopharmacology, $\quad$ 96(1-2): $\quad$ 145-150. https://doi.org/10.1016/j.jep.2004.08.033
[24] Abdiyani, S. (2008). Keanekaragaman Jenis Tanaman Bawah Berkhasiat Obat Di Dataran Tinggi Dien. Jurnal Penelitian Hutan dan Konservasi Alam, 5(1). https://doi.org/10.20886/jphka.2008.5.1.79-92

[25] Kaushal, M., Gupta, A., Vaidya, D., Gupta, M. (2017). Postharvest management and value addition of ginger (zingiber officinale roscoe): A review. IJEAB, 2(1): 397412. https://doi.org/10.22161/ijeab/2.1.50

[26] Dingha, B., Sandler, L., Bhowmik, A., Akotsen-Mensah, C., Jackai, L., Gibson, K., Turco, R. (2019). Industrial hemp knowledge and interest among north Carolina organic farmers in the United States. Sustainability, 11(9): 2691. https://doi.org/10.3390/su11092691

[27] Ingram, J. (2008). Agronomist-farmer knowledge encounters: an analysis of knowledge exchange in the context of best management practices in England. Agric Hum Values, 25(3): 405-418. https://doi.org/10.1007/s10460-008-9134-0

[28] Beach, R., Jones, A., Tooze, J.A. (2008). Tobacco farmer interest and success in income diversification. Journal of Agricultural and Applied Economics, 40(1): 53-71. https://doi.org/10.1017/S1074070800027978

[29] Ann Renninger, K. (2000). Individual interest and its implications for understanding intrinsic motivation. Intrinsic and Extrinsic Motivation, 373-404. https://doi.org/10.1016/B978-012619070-0/50035-0

[30] Jaganathan, D., Bahal, R., Burman, R.R., Lenin, V. (2012). Knowledge level of farmers on organic farming in Tamil Nadu. Indian Res. J. Ext. Edu, 12(3): 70-73.

[31] Marine, S.C., Martin, D.A., Adalja, A., Mathew, S., Everts, K.L. (2016). Effect of market channel, farm scale, and years in production on mid-Atlantic vegetable producers' knowledge and implementation of Good Agricultural Practices. Food Control, 59: 128-138. https://doi.org/10.1016/j.foodcont.2015.05.024

[32] Lemenih, M., Karltun, E., Olsson, M. (2005). Assessing soil chemical and physical property responses to deforestation and subsequent cultivation in smallholders farming system in Ethiopia. Agriculture, Ecosystems \& Environment, 105(1-2): 373-386. https://doi.org/10.1016/j.agee.2004.01.046

[33] Song, S., Arora, S., Laserna, A.K.C. et al. (2020). Biochar for urban agriculture: Impacts on soil chemical characteristics and on Brassica rapa growth, nutrient content and metabolism over multiple growth cycles. Science of the Total Environment, 727: 138742. https://doi.org/10.1016/j.scitotenv.2020.138742

[34] Azizah, N., Purnamaningsih, S.L., Fajriani, S. (2019). Land characteristics impact productivity and quality of ginger (Zingiber Officinale Rosc) in Java, Indonesia. $\begin{array}{llll}\text { Agrivita. J. } & \text { Agr. }\end{array}$ https://doi.org/10.17503/agrivita.v41i3.2321

[35] Riptanti, E.W., Qonita, A., Fajarningsih, R.U. (2018). Potentials of sustainable development of medicinal plants in Wonogiri regency of Central Java province of Indonesia. Bulgarian Journal of Agricultural Science, 24(5): 742-749.

[36] Raei, Y., Alami-Milan, M. (2014). Organic cultivation of medicinal plants: A review. Journal of Biodiversity and Environmental Sciences (JBES), 4(4): 6-18. 